\title{
Reconstructing the Concept of Forest-Based Enterprise Development in Nepal: Towards a Pro-Poor Approach
}

\author{
Bharat Pokharel ${ }^{\star}$, Dinesh Paudel ${ }^{\star}$, Peter Branney\#, Dil Bahadur Khatri ${ }^{\star}$ and Mike Nurse ${ }^{\bullet}$ \\ *Nepal Swiss Community Forestry Project, Kathmandu, Nepal \\ E-mail: bk_pokharel@nscfp.org.np \\ \#Independent Consultant \\ - Regional Community Forestry Training Centre for Asia and the Pacific (RECOFTC), \\ Bangkok, Thailand
}

\begin{abstract}
This paper demonstrates that community forests have high potential to make a significant contribution to rural income and employment through non-timber forest products enterprises particularly to the poor. The paper highlights a practical experience of the pro-poor entrepreneurship approach, its process, steps and outcomes through examination of a recently-developed enterprise in Jiri, Dolakha district of the central hills region of Nepal. The paper concludes that there are five key aspects which need additional attention for a successful pro-poor enterprise: the scale of the enterprise; pro-poor governance of community groups; necessary skills and capacity to empower the poor producers, both socially and economically; partnership building among private, community groups and poor households; and specialized services to tap competitive markets and conducive policy environment.
\end{abstract}

Key Words: community forestry, poverty reduction, enterprise, entrepreneurship, equity, income generation, employment

\section{INTRODUCTION}

\section{The Economic Potential of Nepal's Forest Resources and Missed Opportunities}

In the Master Plan for the Forestry Sector, Community Forestry was considered to be the priority program to fulfil the basic needs of the rural population in the hills of Nepal. National economic benefits were foreseen through the development of wood-based industries and industries based on "minor forest products", as a separate programme among the twelve programmes of the plan. This position was subsequently altered as a result of the Forest Act 1993, empowering communities, through the establishment of Community Forest User Groups (CFUGs), to benefit financially from the sale of forest products commercially harvested from their community forests.

For community forests being managed by CFUGs in the Middle Hills, a later study (World Bank, 1994) estimated that under an intensive forest management regime, these forests that could total about 1.8 million ha after 70 years, could be yielding products valued at NRs. 12.5 billion per year (US\$ $18,000,000)$, taking into account only woody forest products. World Bank (1994) later concluded that there were real financial benefits for households, resulting from a shift to a national strategy for productive, sustainable forest management, as compared with the current less intensive management, if this approach could be combined with attention to other critical external constraints (e.g. marketing and transportation of products). The incremental benefits of making this shift were estimated at NRs 2,390/ha/yr (US\$ 34) for timber; NRs 9,500/ha/yr (US\$ 135) for bamboo and rattan production; NRs 30,700/ha/yr (US\$ 438) for medicinal plants; and NRs $660 /$ ha/yr (US\$ 9) for fuelwood and fodder (ibid). Given the present area of community managed forest (1.3 million ha), these are clearly significant amounts; the relative financial impact of focusing on 'commercial' (i.e. traded) products as opposed to subsistence fuelwood and fodder is also noticeable. Although not all these incremental benefits would accrue to the poorest households, nor would markets for all these products that could become available be readily accessible, the order of magnitude of the potential commercial benefits from community forests can be 
envisaged - very little of which is yet being generated.

Although the Forest Act 1993 provides enabling legislation to permit Forest User Group members to obtain $100 \%$ of all benefits arising from their community forests, a number of regulatory constraints exist. The constraints fall in to two categories: firstly, there is an excessive control orientation to NTFP resources (excessive bureaucratic procedures for collection, transport, processing and sale) and secondly, the permit and royalty systems for collection from governmentmanaged forests do not facilitate sustainable management (Kanel, 1999; Subedi, 1999; (Ojha, 2000). These regulatory constraints are at least partly responsible for the lack of commercial benefits obtained from community forests. In fact, much of the trade in commercial NTFPs is currently controlled by de facto cartels controlled by Indian trading families. We support the view that enterprise development has a significant potential to transform the livelihoods of the rural poor, but also recognise that this opportunity has been missed through approaches that emphasise only subsistence level income generation (through the sale of raw materials) or low wage/part-time rural employment (in existing enterprises that may be managed and/or owned by elites).

These are small numbers, considering that in many parts of the Middle Hills of Nepal most accessible forest (more than 1.3 million ha) has already been handed over to CFUGs and that about 1.4 million households are CFUG members. A recent analysis of enterprise development opportunities for low income producers (Scherr et al., 2004) indicates that it is precisely those conditions that prevail in Nepal (i.e. where there are opportunities for trade in NTFPs with high national or international demand; where there are strong community organisations; where few domestic substitutes are available; and where sustainable management of wild resources is possible) where the greatest market opportunities for the poor lie. This implies that the commercial approach to forest resource utilisation, especially for the direct benefit of poor people, has significant, but as yet largely untapped, potential.

\section{Progress in Enterprise Development in Three Districts of the Middle Hills}

An analysis of the status of forest-based enterprises in three districts in the Middle Hills of Nepal (Dolakha, Ramechhap and Okhaldhunga) between 2002 and 2003 provided a total of 36 operating enterprises (Nurse et al., 2004). In Ramechhap alone, 14 species of non-timber forest products (NTFPs) were being traded in this period, of which up to $46 \%$ of the raw material supply came from community forests. Total forestbased revenue was estimated as NRs. $11,000,000$ (US\$157,000). There was also significant trade in NTFPs as raw materials, for which data had not been collected. This trade is likely to more than double the total revenue for the year.

The poor are largely involved in the collection and sale of raw materials. In parts of Nepal, up to a quarter of the total household income is derived from the sale of non-wood forest products (Scherr et al., 2004). Rural employment is also being generated for men and women (including the poor) through work in processing factories and self-employment is being generated through the sale of raw materials. Community forests are therefore making a significant contribution to rural incomes and employment through NTFP trade, though it is not accounted in the national economy.

However, recent studies in Dolakha, Ramechhap and Okhaldungha (NSCFP, 2003a; 2003b) show that Forest User Groups are currently not getting full value in commercialising their resources. In Ramechhap only $2 \%$ of the total income from forest-based enterprises supplied by CFUGs is going into the CFUG fund (Gronow et al., 2003). Local (usually poor) people primarily benefit from forest-based enterprises through employment opportunities as wages received for collection and transportation, while the CFUGs are primarily receiving royalties for the products, rather than capturing the market value of the resources. With this realisation in mind, CFUGs, private sector entrepreneurs and identified poor CFUG members are, with the help of Nepal Swiss Community Forestry Project (NSCFP), embarking on a programme for piloting enterprise development through a pro-poor entrepreneurship approach. 


\section{THE CONCEPT OF PRO-POOR ENTREPRENEURSHIP EXPLAINED}

\section{Moving Beyond Subsistence}

The origins of Community Forestry in Nepal are rooted in forest conservation and in providing access to household-level forest products' subsistence needs in rural areas. As a result, the conventional approach to Community Forestry implementation over the last 25 years has been one which has focused on a largely subsistence view of forest utilisation. This has proved to be more of a slippery slope than a stepping-stone for the poor rural households (Hobley, 2005). Community Forestry, along with many other facets of rural development in Nepal, has been largely implemented within the prevailing participatory development paradigm. This emphasises the part that local people can play in identifying their own development goals and identifying the paths they wish to take to achieve these. The participatory process itself has achieved much, especially in terms of empowering rural communities and reversing the trend of forest degradation, in the promotion and practicing of inclusive democracy at the local level with proportionate representation of women and dalits in leadership positions, and in acting as a vehicle for community development. However, critics say that Community Forestry has not been successful in terms of being able to provide the benefits equitably to the extreme poor because of its focus on forest protection (rather than production) and subsistence needs (rather than commercial needs). This is evident from a recent analysis of the Operational Plans of community forests, finding that they are still almost exclusively subsistence-oriented (Tumbahangphe, 2005). Focusing on subsistence needs alone within Community Forestry does not provide a sufficient range of benefits to households, especially the poorest households, to significantly change their vulnerable livelihoods situation. Reliance on subsistence and the continuation of a forestdependence role is a particularly inappropriate response for marginal or landless households who simply cannot survive on their own meagre natural resources, regardless of whether their subsistence needs are met or not.

Whilst this problem has been recognised for some time, the responses that have been tried in Nepal have largely focused on providing support for the establishment of forest-based income generation and employment opportunities using the natural resources available from the community forests, often with a strong focus on nontimber forest products (Subedi et al., 2002). Experience from other countries (Antinori and Bray, 2005) has shown that community forest-based enterprises do have some propoor characteristics, such as the ability to combine economic efficiency with equity. This may make them particularly attractive as development interventions. However, experiences from Nepal have led to some questions regarding both the economic sustainability and the level of real benefits for poor people from community forestry enterprises. Approaches frequently fail to recognise the complexities of poor people's livelihoods; poverty is not simply a lack of income and resources, but is also strongly influenced by inequity in decision-making and a lack of social and political capital. These circumstances results in very limited scope for them to develop the skills, knowledge and attitudes that they need to help themselves move out of poverty.

The concept of pro-poor forest-based enterprise is different. It recognises the limitations of these previous approaches that relied on income generation and selfemployment alone. It aims to follow an establishment process leading to a particular enterprise structure that is designed to create livelihood benefits for the poorest households. The pro-poor approach also builds on experience from India (Workshop in Bangalore February, 2003 facilitated by ASCENT- Asia Centre for Entrepreneurial Initiatives) that shows that when poor people are trained as entrepreneurs they can lift themselves out of poverty through a change in their livelihood strategies, for which they previously relied on income from wage labour and/or the sale of raw natural products.

The key elements of the entrepreneurship approach are shown in Table 1. It differs from conventional approaches by working with economic growth and profit as prime drivers (rather than supplementary income or wages) and being managed by the owners (including the poor) rather than other agents, dominated only by elites. 
Table 1. Key elements of income generation, self-employment and entrepreneurship

\begin{tabular}{|l|}
\hline Income Generation \\
\hline Supplementary income \\
\hline Partial employment \\
\hline Usually collective \\
\hline $\begin{array}{l}\text { Managed by NGOs or self- } \\
\text { help groups }\end{array}$ \\
\hline $\begin{array}{l}\text { Most common } \\
\text { development activity }\end{array}$ \\
\hline $\begin{array}{l}\text { Programme aims at skills } \\
\text { training }\end{array}$ \\
\hline $\begin{array}{l}\text { Programme generally } \\
\text { schematic }\end{array}$ \\
\hline Target oriented \\
\hline Group employment \\
\hline $\begin{array}{l}\text { Seldom results in real } \\
\text { income }\end{array}$ \\
\hline
\end{tabular}

Low investment

Self-Employment
Income from one's own
input
Full-time involvement and
employment

Usually not collective

Sometimes part of a selfhelp group

Fairly common

Mainly artisan skills used

Programme generally schematic

\section{Target oriented}

Employment for self only

Not growth oriented

Low investment
Entrepreneurship

Profit

Full-time employment

Individual, partnership, private limited company or group

Managed by owners, partners

Uncommon

Needs more complex skills

Few programmes

Focus on economic viability

Employs more than one person

Economic growth oriented through value addition

Investment may be low or high
The approach being tested emanates from pilot implementation in India that the Nepal Swiss Community Forestry Project has experienced first-hand. Experience shows that most people can be trained conceptually to become entrepreneurs in a number of weeks. They do not have to have an innate gift as had previously been thought.

\section{Reconstructing the View of Forest-based Enterprises}

In the forest sector, the prevailing view is that forest-based enterprises are characterised by being:

- $\quad$ Risky - i.e. not generally appropriate for poor people to become directly involved.

- Dependent on external financial investment, again making them unsuitable for poor people's involvement.

- Usually privately-owned (or more rarely following a co-operative or community-owned institutional models) and beset by inefficiencies and somewhat complex bureaucratic regulations

The Department of Cottage and Small Industries and Company Registered Office register small-scale and community-based enterprises in Nepal. Their records show that there are about 1,331 enterprises based on agricultural and forest resources, of which about 300 are thought to be community-based and run. A more detailed study (Subedi et al., 2002), identified 66 community-based enterprises in the forest sector with five different enterprise ownership structures, none of which was specifically pro-poor (i.e. with ownership at least partially in the hands of poor people).

The initiative for seeking a radically revised view on forest-based enterprise has come from two directions. Firstly, the limitations of income generation schemes and employment to make a significant difference to poor people's lives and, secondly, from the knowledge that forest resources in Nepal offer considerable commercial and economic potential, much of which is still largely unrealised. Community Forestry therefore 
offers an ideal institutional and resource base for this approach. Institutionally, CFUGs that have had its poorer members identified can be externally supported for more equitable outcomes. A network of CFUGs provides an even larger potential resource.

In the next section, we will describe the process, approach and the progress of a Nepali paper processing company that is based in Jiri of Dolakha district. This company adapts a pro-poor entrepreneurship approach and include 126 identified poor households, seven Forest User Groups, 94 local entrepreneurs and four national entrepreneurs as shareholders in a 1.6 million rupees business scheme of which $32 \%$ share comes from external sources on behalf of the identified poor households and the remaining $68 \%$ is met locally.

\section{A CASE OF A NEPALI PAPER PRODUCING COMPANY IN JIRI OF DOLAKHA}

Jiri, in Dolakha District seven hours drive from Kathmandu is a local market centre for the sale of NTFPs. There are a number of existing local enterprises for the trade of raw and semi-processed NTFPs, particularly of Daphne papyracea and D. bholua (Nepali: lokta), Edgworthia gardneri (Nepali: argheli) and Swertia chiraita (Nepali: chiraito). Raw products are traded locally and then may be sold, after further processing, to Kathmandu and through middlemen to India through established (though opaque and monopsonic) market routes.

\section{Shareholding Arrangement and Governance}

A tripartite shareholding mechanism consists of the network of eight CFUGs, 126 identified poor households and private sector partners. A general body of 23 council members and a nine member executive committee are in place to represent these members; all CFUGs, identified poor and private sector investors are members of these bodies. The CFUGs, as a network, have rights over 1,897 hectares of community forests and include 1,393 member households. The CFUGs are either contiguous or are close enough to share Jiri as a sales and processing point and to come to meetings there.

The shareholding and the agreed arrangement of benefits of each partner are shown in Table 2, below.

Table 2. Shareholding and benefits: Jiri Enterprise

\begin{tabular}{|c|c|c|}
\hline Partners & Investment & Benefit \\
\hline 7 CFUGs & $\begin{array}{l}\text { Rs } 323,000 \\
\text { (20\% shareholding) }\end{array}$ & Profit from dividend as shareholder \\
\hline $\begin{array}{l}\text { Identified poor } 126 \\
\text { household }(\mathrm{HH})\end{array}$ & $\begin{array}{l}\text { Rs } 504,000 \\
\text { ( } 32 \% \text { shareholding) }\end{array}$ & $\begin{array}{l}\text { - Profit from dividend as shareholder } \\
\text { - Employment as collector of labour in } \\
\text { processing unit; premium price for forest } \\
\text { products and immediate payment on delivery } \\
\text { - Profit from dividend as CFUG member }\end{array}$ \\
\hline $\begin{array}{l}94 \text { local } \\
\text { entrepreneurs }\end{array}$ & $\begin{array}{l}\text { Rs } 432,100 \\
\text { ( } 28 \% \text { shareholding) }\end{array}$ & Profit from dividend as shareholder \\
\hline $\begin{array}{l}2 \text { national } \\
\text { entrepreneurs based } \\
\text { in Kathmandu }\end{array}$ & $\begin{array}{l}\text { Rs } 321,000(20 \% \\
\text { shareholding) }\end{array}$ & Profit from dividend as shareholder \\
\hline
\end{tabular}

Source: Khadka (2005)

The CFUG fund is significant (though other investment partners have still been required). Kalobhir and Thulonagi CFUG have contributed the highest share of NRs. 100,000 each, whereas Pathibhara has the lowest share of only NRs. 10,000. Although Pathibhara has the largest forestland and has great potential to supply forest products, it is poor in terms of its fund size at the moment. This group in fact is located in a remote area with no access to roads and is a one-day walk from Jiri, whereas Kalobhir and Thulonagi are located around Jiri valley, are connected with the road 
network and are better able to generate revenue. Baisakheswori has selected the lowest number of identified poor households, 14 in total, contributes NRs. 20,000 share from its fund and receives a
NRs. 56,000 share from identified poor. Table 3 below shows the breakdown of the investment of the CFUGs and identified poor households.

\section{Table 3. Breakdown of CFUG Shareholding in the Jiri Enterprise}

\begin{tabular}{|l|r|r|r|r|r|}
\hline $\begin{array}{c}\text { CFUG network } \\
\text { partners }\end{array}$ & $\begin{array}{c}\text { Forest } \\
\text { area (ha) }\end{array}$ & $\begin{array}{c}\text { Household in } \\
\text { CFUGs (No.) }\end{array}$ & $\begin{array}{c}\text { CFUG } \\
\text { share } \\
\text { (NRs.) }\end{array}$ & $\begin{array}{c}\text { Shareholder } \\
\text { identified poor } \\
\text { households (No.) }\end{array}$ & $\begin{array}{c}\text { Identified } \\
\text { poor's share } \\
\text { amount } \\
\text { (NRs.) }\end{array}$ \\
\hline Baisakheswori & 103 & 115 & 20,000 & 14 & 56,000 \\
\hline Thulonagi & 240 & 251 & 100,000 & 24 & 96,000 \\
\hline Hanumanteshwor & 252 & 282 & 25,000 & 18 & 72,000 \\
\hline Kalobhir & 545 & 214 & 100,000 & 19 & 76,000 \\
\hline Pathibhara & 710 & 112 & 10,000 & 16 & 64,000 \\
\hline Namobuddha & 29 & 183 & 30,000 & 20 & 80,000 \\
\hline Kyangesesetup & 18 & 236 & 38,000 & 15 & 60,000 \\
\hline Totals & 1,897 & 1,393 & 323,000 & 126 & 504,000 \\
\hline
\end{tabular}

Source: Khadka (2005)

Apart from the shareholding arrangement, each CFUG provides access to its community forest, through CFUG collector groups that also include identified poor households, supplying raw materials to the company for processing in Jiri at Everest Gateway Herbs Pvt. Ltd., a company registered under a tripartite share-holding mechanism. The company personnel in Kathmandu, national entrepreneurs, have responsibilities for marketing and for business administration, receiving the processed materials from Jiri. The start-up costs and operating costs are borne by the management partners. The Nepal Swiss Community Forestry Project supports the CFUGs in institutional set-up to ensure propoor involvement and for technical aspects of product processing, to match national and international quality standards.

The exact breakdown of the shareholdings, share price, dividends and other costs and benefits has been negotiated based on the business plan. The project provides more formal advice and contributes the amount required for shareholding in the name of the 126 identified poor household shareholders. An experienced management consultant was hired by the company to facilitate the process of preparing the business plan. Various steps were followed to prepare and execute the business plan. A preliminary business plan was prepared in the beginning itself (between step 1 and 2) and a detailed business plan was developed later (between the step 4 and 5). Figure 1 summarises the steps and process. 
Figure 1: The Pro-Poor Enterprise Process (generalised)

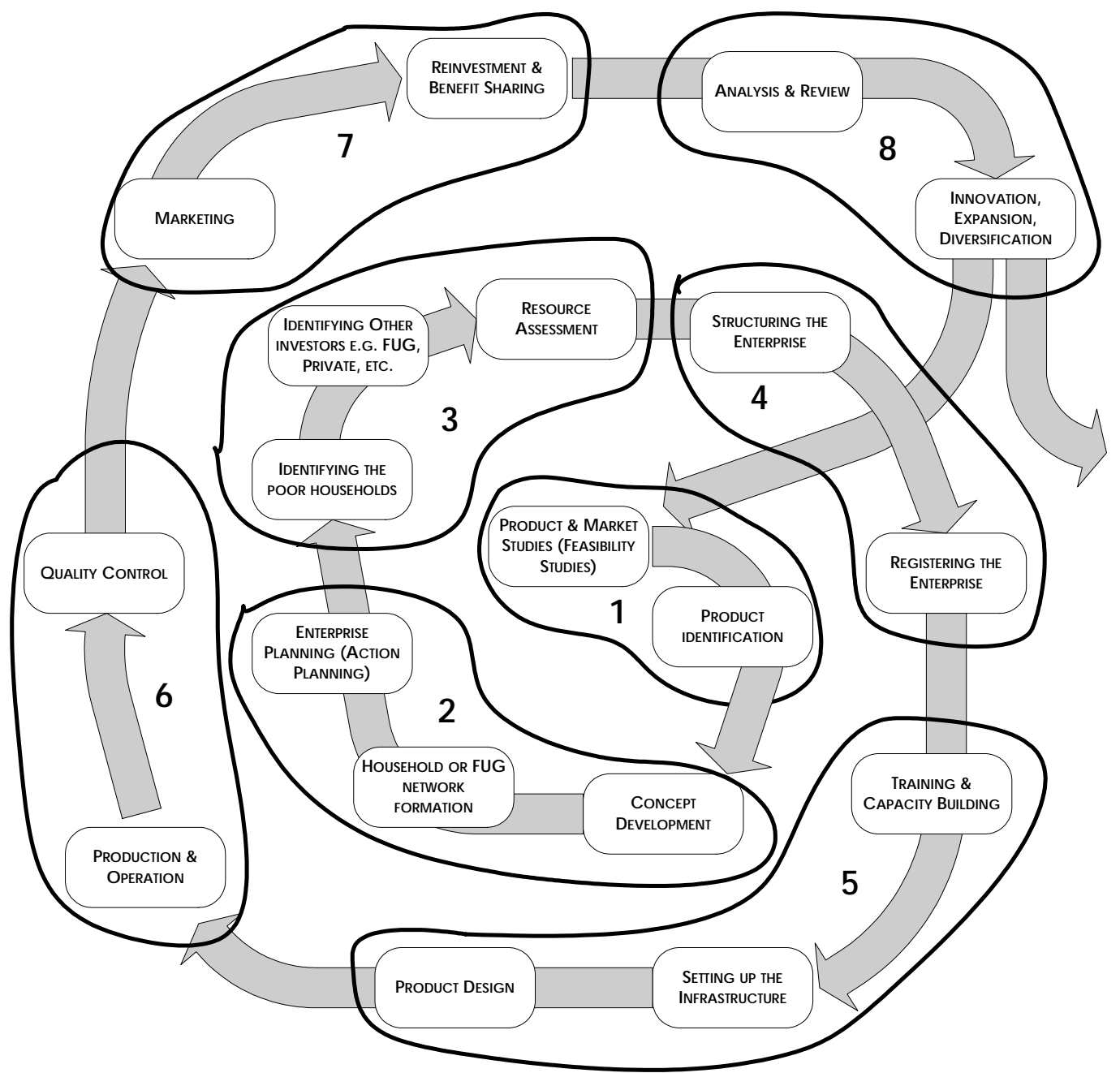

Supply in the Context of Sustainable Forest Management

Data on demand (for subsistence) and supply of forest products, and existing regulations are shown in the Operational Plans of the network member CFUGs. The Operational Plans are revised (or created for new groups) with calculations of sustainable yields for timber and NTFPs, including NTFPs proposed for commercial production. The project has guidelines for inventory for products being proposed for trading in Jiri (NSCFP, 2001). The Operational Plan regulations may also be amended to include provisions for poor collector sub-groups.

\section{ANALYSIS: LESSONS LEARNED, ISSUES AND CHALLENGES}

From two years of development with these enterprises, a number of lessons have emerged, along with a number of critical issues that affect the functioning and effectiveness of pro-poor enterprises.

\section{Demonstration Effect of Pro-poor Enterprise Development}

Although the NSCFP started facilitating the process of establishment of pro-poor enterprises only recently, there are now 
some 84 different types of enterprises in Dolakha, Ramechap and Okhaldhunga, the three Middle Hills districts under investigation, being managed by single households (59), groups of poor households (8), single CFUGs (4), networks of CFUGs like the case studies above (5) and between CFUGs and private partners (8). Products range from paper, essential oils, furniture and timber in CFUGs, to a wider diversity of products (including non-forest products) in individual households. As the enterprises are very new, none have yet recorded profits. Although household-level enterprises seem more effective and profitable, they still lack knowledge of market dynamics, are located in scattered areas and are not networked well. Therefore, they are likely to face marketing challenges in securing more profit.

\section{A Significant Potential Contribution Exists for Poverty Reduction}

Preliminary experience indicates that propoor enterprises can potentially make a significant contribution to poverty reduction through addressing the livelihood needs of poorer Forest User Group households.

There is still a lack of experience of setting up and working with pro-poor enterprises, resulting in only limited availability of evidence of their impact. This will grow as the concept expands. The role of the project is, therefore, to ensure that impact information is systematically recorded and analysed so that it can be used to feedback and adjust PPE processes and associated project support.

\section{Pro-poor Enterprises are not a Panacea for Poverty Reduction}

It is unlikely that pro-poor enterprises will prove to be a panacea for all poor households and all situations. The most disadvantaged households (the so called 'declining poor' - cf. Hobley, 2005) do not have the capacity to enter the trading system as they have neither the skills nor the social capital required. For these households, there still remains the opportunity to benefit from enterprises as 'passive owners', although levels of dividend payments, especially during the early years of such an enterprise, may be low. For these most disadvantaged households, alternative types of external support are also needed, possibly falling under welfare or humanitarian assistance, to ensure their survival. Even for less vulnerable households, additional interventions may be necessary. For example in most pro-poor enterprises, the employment created is still highly seasonal (due to the availability of the forest products). Again the project offers some assistance through the development of household-level livelihoods improvement plans, which are administered by CFUGs. In these plans, household well-being profiles are recorded and livelihood improvement activities are planned and implemented.

Finally, since the pro-poor enterprise approach is demand-driven (rather than resource-driven), this may mean that in some CFUGs, products that can be processed or sold to a market may not be available. In such situations, there are a number of possibilities:

- The CFUG could become part of a cluster or network of CFUGs to gain access to wider resources.

- A pro-poor enterprise could be based on non-forest product related activities (e.g. handicrafts, livestock, etc.).

- Since most CFUGs have some timber, this could also become a source of raw material for the propoor enterprise (e.g. for furnituremaking, charcoal, etc.) which could generate additional profits.

\section{The Pro-poor Enterprise Establishment Processes is Complex}

It has been pointed out that the management structures for pro-poor enterprises and the processes required to establish them are unduly complex (Conrad, 2005) and will make their sustainability precarious. Complexity is of course relative, and very similar arguments were raised during the early years of Community Forestry in Nepal, when processes for CFUG formation were being developed that were also seen to be too complex to be replicated. In this case, the institutions (CFUGs) have survived and in many cases thrived and there is no reason to suppose that pro-poor enterprises cannot do likewise.

Social processes, institution formation, and addressing issues of accountability and 
transparency are invariably not straightforward, especially when compared with conventional enterprises where there may be a single owner and a simple management structure. The role of external facilitation of these processes (e.g. through governance coaching), are vital to ensuring their success, especially in the inclusion and participation of women and disadvantaged groups in the enterprise management structure and in the eventual benefitsharing mechanisms.

\section{The Capacity of Members and Partners in Pro-poor Enterprises is Low}

The initial capacity of those involved with pro-poor enterprises may be low. They may not have been previously involved with enterprises, and they may have little experience of working in a commercial (as opposed to subsistence) environment. The capacity of enterprise members, especially the selected board members, as entrepreneurs and business managers is critical to the success of the enterprise. So far, experiences have indicated that the relevant skills and capacity can be effectively built - this being a key project role. As propoor enterprises grow and expand, the professional entrepreneurship skills of the members will improve. The role of the private sector investors is also important here, since not only do they bring finance to the enterprise, but they can also contribute their skills in business management and marketing.

\section{The Scope for Improved Technologies for Resource Management and Product Processing}

Existing pro-poor enterprises are largely based on simple and known technologies for processing of raw forest products. It is likely that there are many simple technologies available in the region (e.g. in India) that may be highly appropriate for the pro-poor enterprise situation in Nepal. This is an important role for external (project or trade association) support.

On the resource side of the enterprise, there has, as yet, been very limited development of technologies for sustainable resource management for specific purposes, such as for the management of forests for enhanced production of a specific NTFP or fruit. Again, there is considerable scope for improving this technology aspect. For example, contractors from within and outside the CFUG membership in the Jiri case above are involved in annual collection and trade in NTFPs. Every year, all accessible lokta and argheli, is harvested. Outside contractors need to be excluded and contractors inside the CFUG network regulated with quotas based on community forest inventory and specific harvesting guidelines for each product. The CFUGs need also monitor offtake of products accurately.

\section{Market Development and Marketing Capacity Remain Weak}

For established enterprises, it is probably in the area of marketing that they have so far shown themselves to be weakest, although again this is still an early stage for most and it is likely that they will develop their skills in this over time. However, physically located in remote hill districts and with most product markets lying in Kathmandu and elsewhere, pro-poor enterprises in the project area are at a significant disadvantage as compared to those enterprises located in urban centres. External support for developing market linkages is therefore now an important need, particularly since enterprises are starting to get into full operation mode and expand their output.

Although most pro-poor enterprises start off with a single product and single market, eventually the response of effective enterprises (and entrepreneurs) will be to respond to markets by diversifying and extending the original product concept in order to put themselves in a more competitive marketing position. In some cases, economies of scale will also encourage increased production levels, again requiring expanded markets. Some pro-poor enterprises have already reached this stage and are now looking for more expanded or diversified product ranges.

Although it is expected that certain specialised labels such as 'certified' and 'fair-traded' will provide an additional market pull for products from pro-poor enterprises, these types of markets are not yet well developed in Nepal. In order to take advantage of them, it may be necessary for external support to be addressed towards 
supporting their development in Nepal or facilitating market links into these types of markets where they already exist overseas.

A possible approach to addressing the inherent weaknesses of newly established pro-poor enterprises in market approaches would be to more closely involve agencies that already have skills and experiences in marketing (invariably, this would be the private sector) as shareholders of the enterprises. To some extent this is already happening as private shareholders are included in some pro-poor enterprise models. However, there is considerable scope to extend this approach to bring in shareholders that have these key marketing skills as well as capital.

\section{There are Opportunities to Improve the Regulatory Environment for Pro-poor Enterprises}

In Nepal, the policy, regulations and overall enabling environment for Community Forestry have been developed and refined over the past two decades and are now largely supportive. However, these have tended to assume that community forests would be managed primarily for meeting subsistence needs of CFUG members and have not really anticipated the emergence of CFUGs as entrepreneurs, managing commercial forest product-based businesses and fully utilising the resources available from their community forests. Recent experiences with the establishment and operation of pro-poor enterprises in these three districts of the Middle Hills has highlighted a number of issues concerning policy, regulations, and overall attitudes to pro-poor enterprises that act as constraints to their functioning as successful businesses and their ability to have direct impacts on poverty. Some of these include:

(i) The lack of any specific rules and regulations to support communitybased enterprises. Co-operatives are governed by the co-operatives regulations but these differ from the requirements of pro-poor enterprises, which have a greater focus on entrepreneurship and market-driven approaches.

(ii) The forestry law (Forest Act 1993 and associated regulations) does not clarify a number of the detailed points about the commercial use of forest products by communities. While there are legal provisions for the regulation of the timber and NTFP trade, this applies mainly to contractors and government managed forests rather than CFUG-managed enterprises.

(iii) Company registration (even for smallscale pro poor enterprises) is a lengthy and tedious process. Companies must appear in Kathmandu to be registered. therefore, hiring a legal advisor (at cost) is often necessary. In addition, enterprises need to renew their registration every year for which a number of documents are again required.

(iv) In the district, enterprise registration needs a recommendation from the DFO. There is a legal regulation that a forest product processing factory should be located more than $3 \mathrm{~km}$ from the nearest forest. This does not make sense for the efficient operation of such enterprises.

(v) Transport of forest products (both raw and processed) with release orders having to be provided by DFOs can prove to be a slow process and one that is liable to petty corruption and delays, particularly in situations where the attitude of DFOs is that enterprises need to be controlled rather than supported. At checkpoints and stops, bribe-seeking (common in the contractor-based business model) have important negative impacts on pro-poor enterprises.

(vi) For some products (e.g. food stuffs) where quality sampling is necessary, delays are created since the Quality Control Department of the government is in Kathmandu and because there is no on-site checking and monitoring service. Bringing samples of every batch of produce to Kathmandu is time consuming and expensive.

The result of these 'grey areas' in the forestry and business regulations means that their interpretation is frequently left to the individual DFO. This causes some uncertainty and can lead to unnecessary 
delays, adding to the overhead of the enterprise.

\section{Dealing with Risk}

Poor people live in a risk-laden environment. Investment in pro-poor enterprises (or any kind of commercial enterprise) might be considered as an additional risk for already vulnerable households to bear. Since poor households are already very vulnerable, it is useful to consider whether becoming involved in pro-poor enterprises implies a lesser risk or not. Ultimately, time will show how sustainable pro-poor enterprises are. This evidence will of course be available for poor households to decide for themselves whether or not their involvement will contribute to their sustainable livelihoods. However, compared with conventional enterprises, the risks of pro-poor enterprises, especially for poor households, have been lessened in a number of ways:

a) Low Investment (i.e. no direct financial investment by poor households) Overall levels of investment in the pro-poor enterprises are low anyway.

b) Appropriate Technology. This contributes to the lower levels of investment. It is also important because it contributes to employment and job security, which are significant benefits for poorer households.

c) Increased Capacity for Management and Entrepreneurship. If this can be successfully achieved, then the various aspects of successful business management would be applied (e.g. in business planning, organisational skills, market skills, accountability and transparency)

d) Project and other External Support. This support on behalf of poor households (e.g. to cover the costs of their shareholding or providing collectors an immediate premium price on raw material supply) lessens their exposure to risk.

e) Private Sector Involvement. To an extent under the pro-poor enterprise model, private investors (if involved) bear the greater share of risk since they have to contribute their own financial resources. If they consider the enterprise safe enough to invest, then it is also likely to be safe for poor households.

\section{CONCLUSION}

The greatest potential for lifting the poor out of poverty lies with enterprise development, through community forestry, particularly if an entrepreneurship model is used.

"Few economic sectors benefit the poor disproportionally. But there is ample evidence that successful commercialisation by small-scale, low income producers provides much higher economic and employment multipliers than most other patterns of economic growth. There is reason to believe that such benefits would also accrue to millions of poor rural people with successful commercialisation of locally produced forest products and services." (Scherr et al., 2004: 129)

CFUG producers needed skills in a number of new areas to build their capacity for enterprise development and management, including, inter alia:

a) Business development services that respond to diversified products and services to balance variable period income streams (seasonal as well as short and long term benefits) and risk

b) Market information

c) Legal advice

d) Technical advisory services and training courses (e.g. in production, processing, environmental management/pollution control and sustainable forest management)

e) Financial analysis

f) Linkages to political supporters

g) Mobilisation of investment funding through grant or credit lines, and

h) Assistance with forest planning and certification $^{1}$ (Scherr et al., 2004)

1 Certification systems required include organic certification; FSC certification for sustainable timber and NTFP extraction, chain-of-custody certification and ISO management certification. 
For local people to realise these potentials, they must improve their market position, develop strategic business partnerships and pursue new sources of financing. There is a need to adapt certification for NTFPs and small-scale timber production and encourage the development of business services to meet commercial CFUG needs (Scherr et al., 2004).

The project and other external service providers (e.g. FECOFUN, trade associations) will need to undertake further research and develop those skills in CFUGs themselves and in specialist service providers. It will also need to support policy analysis and debate to promote open and competitive markets ${ }^{2}$.

The authors conclude that the prevailing views of forest-based enterprise are not only incorrect, but that they unnecessarily limit the scope for forest-based enterprises in a way which prevents them from realising their full potential, particularly in terms of livelihoods impacts on poorer households and wider economic development. This fieldbased experience indicates that pro-poor enterprises that differ radically from the conventional models of community forestbased enterprises can have significant poverty impacts.

It is clear that there is a need to pilot innovative approaches, to complement more conventional and development oriented methods that are based on market chain analysis, income generation and selfemployment. The successful pilots can then serve as "beacons, to convince policy makers and business people that this new paradigm is indeed worth pursuing" (Scherr et al., 2004:139).

\section{ACKNOWLEDGEMENT}

Authors would like to acknowledge Nepal Swiss Community Forestry Project (NSCFP) for all the information and reading materials. Email: adm@nscfp.org.np. NSCFP is a bi-lateral assistance project funded by SDC and managed by Intercooperation, the Swiss Foundation for International Development based in Switzerland.

2 Tied credit deals between Indian marwhadi traders and rural collectors are common for many forest and agricultural products in Nepal.

\section{REFERENCES}

Antinory, C. \& Bray, D. B. 2005. Community Forest Enterprises as Entrepreneurial Firms: Economic and Institutional Perspectives from Mexico. World Development, 33(9): 1529-1543.

Conrad H. 2005. Report on Mission for Everest Gateway Herbs Ltd. Consultancy Report. Kathmandu: NSCFP.

Gronow, J.; K. Singh; Branney P. \& Kafley, G. P. 2003. Nepal Swiss Community Forestry Project External Review - June 2003. Kathmandu: His Majesty's Government of Nepal \& the Swiss Agency for Development and Cooperation.

Hobley M. 2005. Where in the World is there Pro-poor Policy and Tenure Reform? Unpublished Presentation.

Kanel, K. R. 1999. Analysis of Policy and Regulatory Constraints in the Development of Non Timber Forest products in Nepal, Consultancy Report. Kathmandu: WWF, USA.

Khadka, I.B. 2005. Report presented in the First General Assembly of the Everest Gateway Company. Kathmandu: NSCFP.

Mahanty, S.; Gronow, J.; Nurse, M. \& Malla. Y. Reducing Poverty through Community Based Forest Management in Asia. Forest and Livelihood, 5 (1): 78-89.

NSCFP. 2001. Participatory Inventory Guidelines for Non-Timber Forest Products. Vol. 1, Edition 1. Kathmandu: NSCFP.

NSCFP. 2003a. Forest Based Enterprises and Trade Status in Dolakha District. Kathmandu: NSCFP.

NSCFP. 2003b. Forest Based Enterprises and Trade Status in Ramechhap District. Kathmandu: NSCFP.

Nurse, M.; Khatri, D. B.; Paudel, D. \& Pokharel B. 2004. Rural Entrepreneur Development: A Pro-poor Approach to Enterprise Development through Community Forestry. In Twenty Five Years of Community Forestry: Proceedings of the Fourth National Workshop on Community Forestry, (pp. 250-258). Kathmandu: Community Forestry Division, Department of Forest.

Ojha, H. 2000. Current Policy Issues of NTFP Development in Nepal. Kathmandu: Asia Network for Sustainable Agriculture and Bioresources (ANSAB). 
Pokharel, B. \& Nurse, M. 2004. Forest and Peoples' Livelihoods: Benefiting the Poor

from Community Forestry. Forest and Livelihoods, 4(1): 19-29.

Scherr, S. J.; White, A. \& Kaimowitz, D. 2004. A New Agenda for Forest Conservation and Poverty Reduction. Making Markets Work for Low Income Producers. Washington DC: Forest Trends.

Subedi, B. 1999. Non Timber Forest Products Sub-Sector in Nepal: Opportunities and Challenges for Linking Business with Biodiversity Conservation. A Paper Prepared for the Workshop on Natural Resources

Management for Enterprise Development in the Himalayas, Nainital, India.

Subedi, B. P.; Ojha, H.; Nicholson K. \& Binayee, S. B. 2002. An Assessment of
Community Based Forest Enterprises in Nepal: Case Studies, Lesson and Implications. Kathmandu: ANSAB.

Tumbahangphe N. 2005. Translating Policy into Implementation Mechanism in Community Forestry, Nepal. Analysis and Synthesis of Constitutions and Operational Plans of the Community Forest Users Groups in the Policy Framework. Kathmandu: NORMS and FECOFUN.

University of California, Berkeley. 2005. Everest Gate-Way Herbs Private Limited. Operational Business Plan. Kathmandu: NSCFP.

World Bank. 1994. Forestry Sector Potential and Constraints: An Unpublished Report Prepared by J. Gayfer and P. Tamrakar. Kathmandu: World Bank. 